\title{
Real Money Investors and Sovereign Bond Yields
}


Real Money Investors and Sovereign Bond Yields

Laura Jaramillo and Y. Sophia Zhang 


\title{
IMF Working Paper
}

Fiscal Affairs Department

\author{
Real Money Investors and Sovereign Bond Yields* \\ Prepared by Laura Jaramillo and Y. Sophia Zhang \\ Authorized for distribution by Julio Escolano
}

November 2013

\begin{abstract}
This Working Paper should not be reported as representing the views of the IMF. The views expressed in this Working Paper are those of the author(s) and do not necessarily represent those of the IMF or IMF policy. Working Papers describe research in progress by the author(s) and are published to elicit comments and to further debate.
\end{abstract}

\begin{abstract}
Experience from the global financial crisis suggests that countries' borrowing costs are not solely determined by macro and fiscal fundamentals. Factors such as ownership structures of government securities, among others, also play a significant role. This paper investigates the effect of "real money investors"- domestic nonbanks and national and foreign central banks - on bond yields for a sample of 45 advanced and emerging market economies. The results show that, while bond yields rise with the debt to GDP ratio, this increase is partly offset if this debt falls in the hands of real money investors. Nonetheless, for some countries there is the risk that such ownership structure could change over the long run, which would impose upward pressure on borrowing costs, especially where fiscal positions are weak.
\end{abstract}

JEL Classification Numbers: E44, G11, G15,H63

Keywords: Public Debt, Government Bonds, Investor Base, Advanced Market Economies, Emerging Market Economies

Author’s E-Mail Address: ljaramillomayor@imf.org; yzhang@imf.org

\footnotetext{
* We thank Carlo Cottarelli, Phil Gerson, Martine Guerguil, and Marialuz Moreno Badia for helpful comments and discussions. We are grateful to participants at the Fiscal Affairs Department seminar on this research for their useful suggestions. We would like to thank Serkan Arslanalp and Takahiro Tsuda for access to their database on the breakdown of sovereign debt holdings. Raquel Gomez provided excellent research assistance.
} 


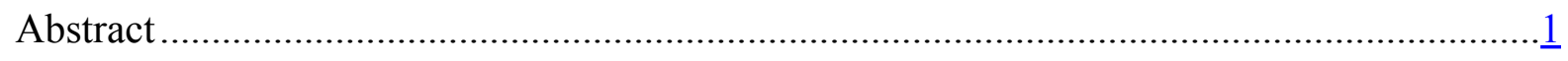

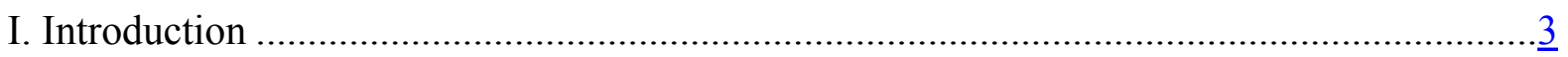

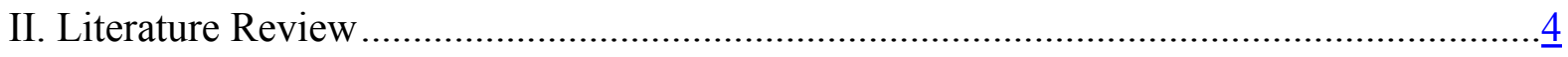

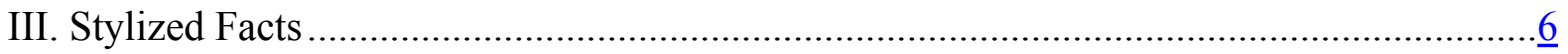

IV. Empirical Model Specification ......................................................................

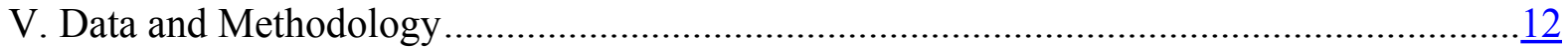

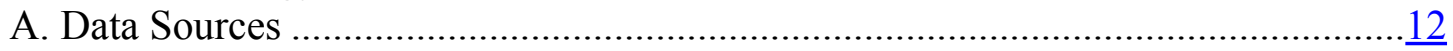

B. Results and Policy Implications .............................................................

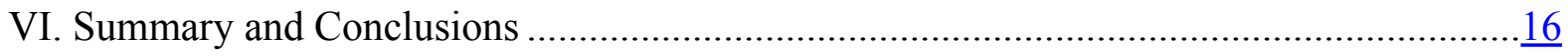

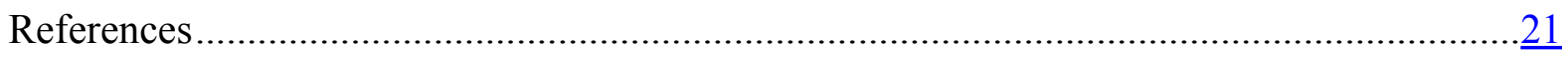

Table

1. Determinants of Sovereign Bond Yields ............................................................ 18

Figures

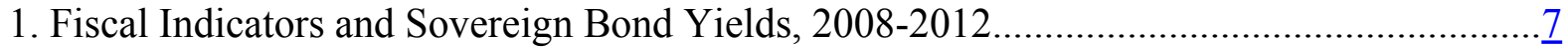

2. Real Money Investors and Sovereign Bond Yields, 2008-2012 ...................................

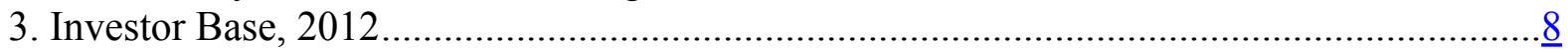

4. Investor Base by Region, 2004-2012 …...............................................................

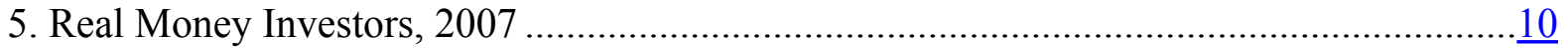




\section{INTRODUCTION}

Since the start of the global financial crisis, the sharp contrast in the level of bond yields among countries with similar deteriorations of their fiscal accounts suggests that one must look beyond just fiscal fundamentals for an explanation. The composition of countries' investor bases sheds light on other important factors that drive these developments. Indeed, "real money investors"comprising institutional investors (such as pension funds, mutual funds, and insurance companies), retail investors (such as households and nonfinancial corporations) as well as national and foreign central banks - are typically unleveraged, tend to have strong preferences for specific maturities also for reasons other than returns, and are thus able to provide a more stable source of demand for government debt. ${ }^{1}$ While many studies have looked at the impact of different types of investors on an individual basis in the case of U.S. Treasury bond yields, the analysis from a cross-country perspective that looks concurrently at several types of investors has been limited.

This paper attempts to fill this gap by investigating the effect that the holdings of general government debt by real money investors, in particular domestic nonbanks and national and foreign central banks, can have on long-term sovereign bond yields across a broad sample of advanced and emerging market economies. Based on semi-annual panel dataset for 24 advanced and 21 emerging market economies between 2004 and 2012, a Hausman-Taylor model shows that the real money investors have a significant effect on bond yields in both advanced and emerging market economies. ${ }^{2}$ For every percentage point increase in the debt-to-GDP ratio, the long-term bond yield is expected to be 1-3 basis points higher. However, if that debt is in the hands of real money investors, then this would more than offset the impact on bond yields, with a larger impact in emerging market economies. Higher domestic nonbank holdings of one percent of GDP would reduce bond yields by 3 to 8 basis points. Higher national and foreign central bank holdings of one percent of GDP would reduce bond yields by 4 to 18 basis points, though in the case of emerging market economies this would be counterbalanced if central bank intervention results in inflationary financing.

These findings confirm that in the near term real money investors help to lower bond yields, but they also underscore the importance of debt reduction efforts by countries with high debt to GDP ratios. Capacity for real money investors to absorb public debt may diminish over the long term for some countries. For example, population ageing is likely to reduce savings in Japan, curbing the size of domestic nonbank financial institutions. Chinese central bank holdings of U.S. Treasury bonds may also decline if there is diversification away from U.S. dollars or as it

\footnotetext{
${ }^{1}$ This definition of institutional investor base is chosen to ensure comparability across a wide set of advanced and emerging market economies. Lack of data for this broad set of economies does not allow for the distinction of other investors such as unleveraged nonresident funds, which could be important sources of financing in some countries.

${ }^{2}$ Advanced countries include Australia, Austria, Belgium, Canada, Czech Republic, Denmark, Finland, France, Germany, Greece, Ireland, Italy, Japan, Korea, Netherlands, New Zealand, Norway, Portugal, Slovenia, Spain, Sweden, Switzerland, United Kingdom and United States. Emerging market economies include Brazil, Bulgaria, Chile, China, Colombia, Hungary, India, Indonesia, Latvia, Lithuania, Malaysia, Mexico, Peru, Philippines, Poland, Romania, Russia, South Africa, Thailand, Turkey, and Ukraine.
} 
implements policies to slow the accumulation of foreign exchange reserves. Also, quantitative easing strategies by national central banks in the U.K. and U.S. are also expected to eventually unwind. Financial sector reform in emerging market economies could also allow domestic nonbanks to diversify away from government securities. Hence, the risk of potential change of ownership structure to less participation from real money investors induced by any of the above reasons could imply upward pressure on the governments' borrowing costs, especially if their fiscal fundamentals remain weak. It is therefore essential that countries with high debt-to-GDP ratios reduce risk by moving steadily ahead with medium-term fiscal consolidation.

The remainder of this paper is structured as follows. Section II reviews the existing literature on the effect of the investor base on bond yields in advanced and emerging market economies. Section III discusses stylized facts on the relationship between real money investors and sovereign bond yields. Section IV provides the empirical model specification while Section V provides the estimation results and discusses policy implications. Section VI concludes.

\section{LITERATURE REVIEW}

Our theoretical motivation follows the preferred-habitat models of Vayanos and Vila (2009) and the extension by Kaminska, Vayanos, and Zinna (2011), who provide a framework for understanding how the supply of assets of different maturities might influence their respective yields. ${ }^{3}$ According to preferred-habitat view, there are investor clienteles with preferences for specific maturities, and the interest rate for a given maturity is influenced by the demand of the corresponding clientele and the supply of bonds with that maturity. The theoretical model allows for demand and supply effects on bond prices, while imposing the discipline of no arbitrage. Interest rates are determined through the interaction of so-called preferred-habitat investors (investors with strong preferences for specific maturities also for reasons other than returns) and risk-averse arbitrageurs (who trade bonds at different maturities for returns considerations). Therefore, in contrast to common term structure models (Cox, Ingersoll, and Ross, 1985), there are heterogeneous clienteles. Arbitrageurs incorporate expected short rates into bond prices and bring yields in line with each other by smoothing demand and supply pressure. These arbitrageurs trade the slope of the term structure by buying (selling) long-term bonds and selling (buying) short-term ones. In bridging markets across different maturities, arbitrageurs face both fundamental and non-fundamental risk. The fundamental risk is that the short-term interest rate rises (falls) in the future, thereby flattening (steepening) the term structure. The non-fundamental risk is that there will be shocks to the demand for bonds with particular maturities. Since arbitrageurs are risk-averse, they demand higher compensation as their relative exposure to long bonds increases and therefore investor demand for particular maturities has an effect on the bond risk premia.

Several studies have likened the characteristics of demand for sovereign bonds by real money investors - here defined to include institutional investors, retail investors and national and

\footnotetext{
${ }^{3}$ The position that longer-term yields depend in part on the relative quantities outstanding of longer-term assets in the hands of the private sector (including commercial banks) was the subject of a substantial literature in the 1950s and the 1960s (see Culbertson, 1957; and Modigliani and Sutch, 1966).
} 
foreign central banks - to the demand of preferred-habitat investors. D'Amico and others (2012) identify the scarcity channel associated with the traditional preferred habitat literature as one of the principal transmission channels for the U.S. Federal Reserve's recent Large-Scale Asset Purchase Programs. Sierra (2010) shows that foreign official flows into U.S. Treasury securities appear similar to relative supply shocks, and suggests that foreign officials are akin to preferredhabitat investors. Krishnamurthy and Vissing-Jorgensen (2010) present anecdotal evidence that foreign central banks buy U.S. Treasuries regardless of their prices relative to other assets. Foreign officials are thus unlikely to exploit relative price differentials across the terms structure, which makes them similar to preferred-habitat investors. Furthermore, IMF (2011), based on Emerging Portfolio Fund Research data for some 20,000 equity funds and 10,000 bond funds between January 2005 to May 2011, finds that interest rate differentials do not significantly affect real-money investment flows, which would be consistent with preferredhabitat investors. ${ }^{4}$

Empirically, several studies provide evidence for the relationship between foreign central banks and sovereign bond yields in the case of the United States. Kaminska, Vayanos and Zinna (2011) find that the decline in long-term rates in 2004-05 in the United States despite rising policy rates is driven by a rising preferred-habitat demand linked to foreign official holdings of longer-term U.S. Treasury securities. Krishnamurthy and Vissing (2010) find that foreign officials' purchases reduce the supply of safe assets available to the rest of investors and hence drive up the convenience yield. They also find that if foreign officials were to sell their holdings, the effect would be to raise long-term Treasury yields by 59 basis points relative to the Baa corporate bond yield. Sierra (2010), through a series of forecasting regressions of realized excess returns on measures of net purchases of Treasuries, finds that official flows appear similar to relative supply shocks that decrease the amount of bonds available, drive up their prices and thus decrease yields through the component related to excess returns. Beltran and others (2012) estimate that, if foreign official inflows into U.S. Treasuries were to decrease in a given month by US $\$ 100$ million, 5-year Treasury rates would rise by about 40-60 basis points in the short run, and 20 basis points in the long run. Warnock and Warnock (2009) also find foreign purchases of U.S. government bonds have an economically large and statistically significant impact on long-term interest rates. They estimate that absent the substantial foreign inflows into U.S. government bonds the 10 -year Treasury yield would be 80 basis points higher. In a cross-country analysis for a set of 22 advanced economies, Arslanalp and Poghosyan (2013) find that a one percentage point rise in the foreign official share in total debt leads to a 7 basis points decrease in bond yields. ${ }^{5}$

Other studies have also found a significant relationship between real money investor holdings and government bond yields in advanced economies. Greenwood and Vayanos (2010) present two episodes that support the preferred-habitat view. They show that long-term interest rates

\footnotetext{
${ }^{4}$ For the case of insurers, Chen and others (2013) find that insurers' portfolios exhibit restrained elasticities to interest rate changes, also consistent with preferred-habitat investors.

${ }^{5}$ Views denying any effect from foreign official purchases on U.S. bond yields have also been put forward. See ECB (2006).
} 
experienced large and long-lasting shifts because of regulation-induced change in the demand of a long-maturity clientele in the case of the U.K. pension reform of 2004, and a governmentinduced change in the supply of long-term bonds in the case of the U.S. Treasury's buyback program of 2000-2001. Gagnon and others (2010) present evidence that the U.S. Federal Reserve asset purchases, including of U.S. Treasuries, led to economically meaningful and long-lasting reductions in longer-term interest rates on a range of securities. D'Amico and King (2010) find that each purchase operation in the context of the 2009 Large Scale Asset Purchases (LSAP) by the U.S. Federal Reserve, on average, caused a decline in yields in the sector purchased of 3.5 basis points on the days when these purchases occurred and a persistent downward shift in the yield curve of as much as 50 basis points, with the largest impact in the 10- to 15-year sector. Joyce and others (2011) find that asset purchases by the Bank of England in the context of its recent quantitative easing program depressed medium to long term government bond yields by about 100 basis points. For G20 advanced economies, Andritzky (2012) finds that domestic institutional investors are associated with lower yields, though public sector holdings, including central banks, are not. Based on a sample of 12 advanced economies, Arslanalp and Lam (2013) find that central banks' holdings rather than holdings by domestic financial institutions reduce bond yields. They also find that higher holdings of government securities by the foreign nonofficial sector tend to raise yields, but this does not seem to be statistically significant.

In the case of emerging market economies, the impact of the investor base on bond yields has been relatively unexplored. Peiris (2010) finds, based on a panel data analysis of 10 emerging markets, that greater foreign participation in the domestic government bond market tends to significantly reduce long-term government yields, while there is no evidence that volatility necessarily increases. Other studies have focused on the impact of nonresident holdings of government debt (i.e. external debt) on sovereign foreign currency spreads, without distinguishing by type of investor. Ferrucci (2003), Bellas and others (2010), and Dell'Erba and others (2013) all find that the external public debt to GDP has a significant and positive effect on sovereign spreads.

\section{StYlized FACTS}

Since the start of the global financial crisis, the sharp contrast in bond yields among countries with similar deteriorations of their fiscal accounts suggests that one must look beyond just fiscal fundamentals for an explanation. Figure 1 shows that countries with higher debt to GDP ratios did not necessarily have the highest bond yields. This is also the case in terms of the overall balance to GDP. This suggests that other elements beyond traditional fiscal indicators must be looked at carefully to analyze the behavior of bond yields. The composition of countries' investor bases sheds light on other important factors that drive these developments. Figure 2 illustrates that countries with a higher share of real money investors tend to face lower financing costs. 
Figure 1. Fiscal Indicators and Sovereign Bond Yields, 2008-2012
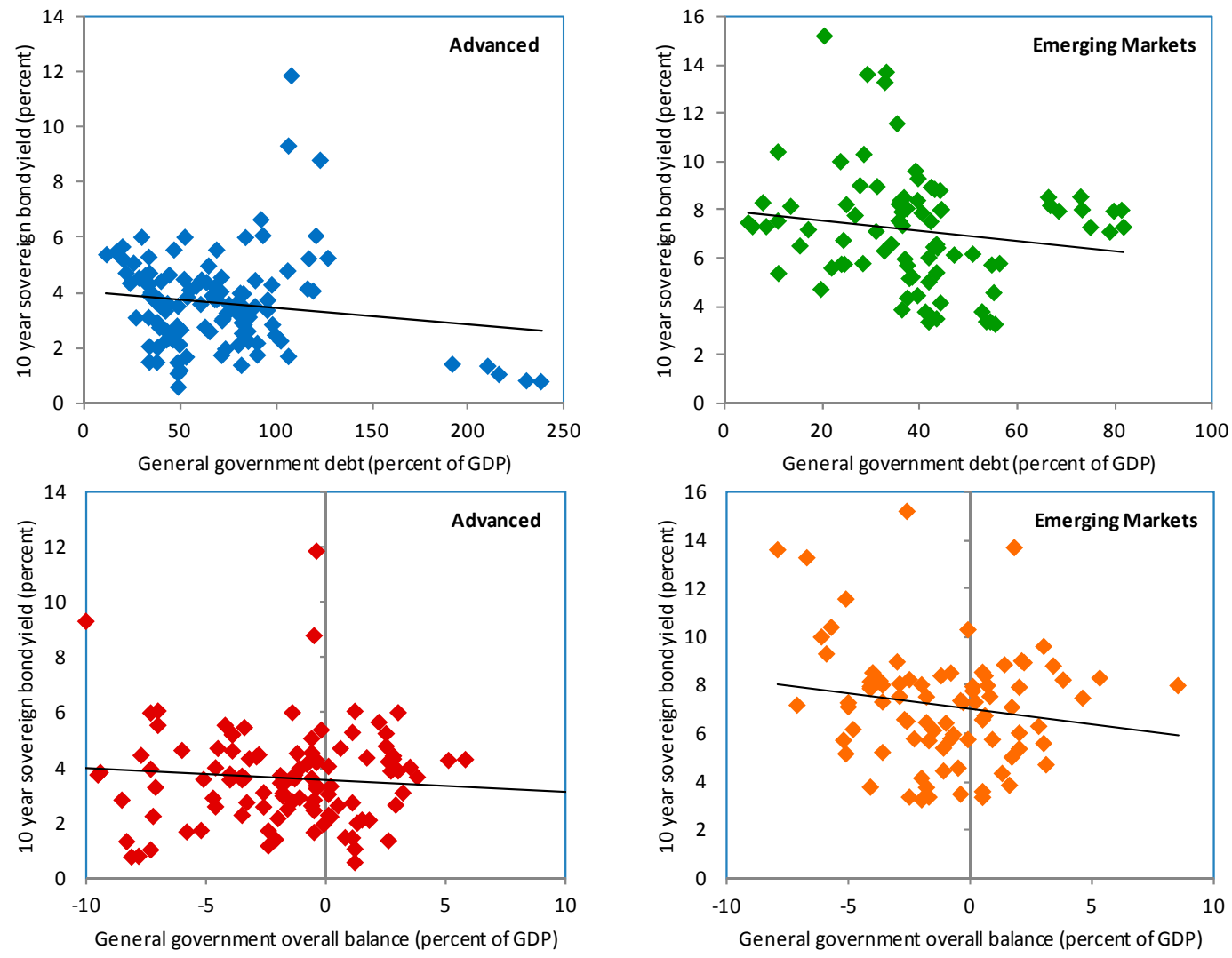

Sources: World Economic Outlook, Bloomberg, L.P., Haver Analytics, IMF International Finance Statistics, and authors' calculations.

Figure 2. Real Money Investors and Sovereign Bond Yields, 2008-2012
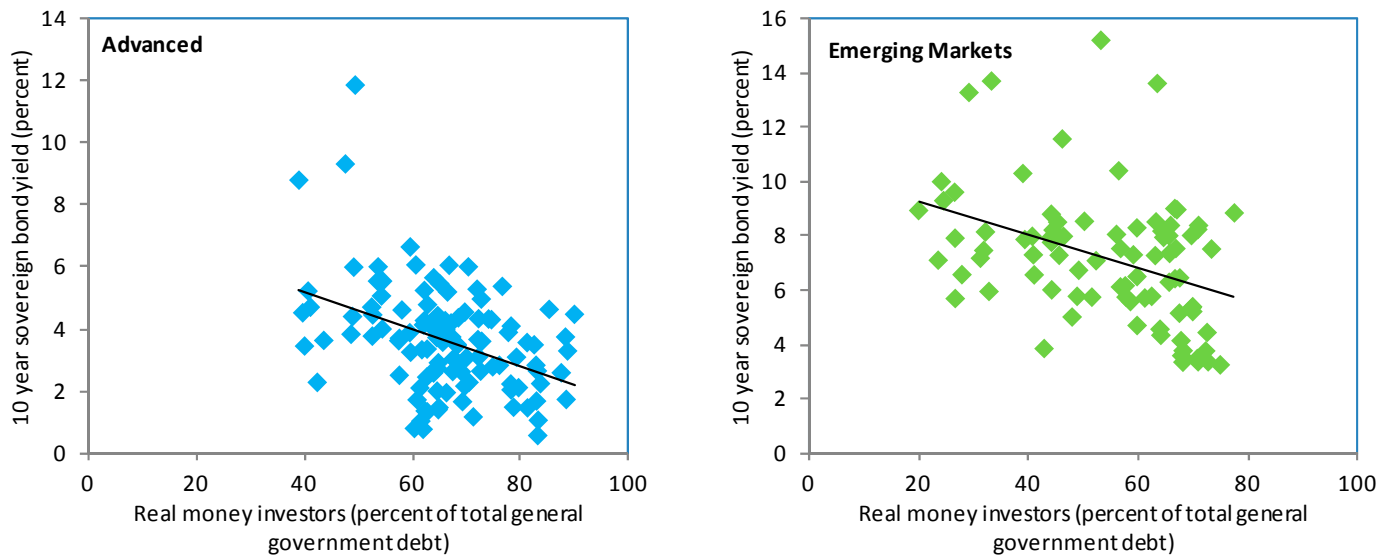

Sources: Arsanalp and Tsuda (2012, 2013), World Economic Outlook, Bloomberg, L.P., Haver Analytics, IMF International Finance Statistics, and authors' calculations.

Note: Real money investors includes domestic institutional investors, domestic retail investors, and national and foreign central banks. 
In general, real money investors in advanced economies hold a larger share of government debt than in emerging economies. Figure 3 shows the composition of the investor base of government debt for 2012. ${ }^{6}$ On average, real money investors hold 48 percent of advanced economy debt, of which 29 percent is held by domestic nonbanks and 18 percent held by national and foreign central banks. In the case of emerging economies, 35 percent of debt is in the hands of real money investors, 28 percent of which by domestic nonbanks and 7 percent by the national central bank. The shares of national central bank holdings of government debt are comparable across advanced and emerging market economies. However, a notable difference is that in advanced economies 14 percent of debt is in the hands of foreign central banks compared to none in the case of emerging economies.

Figure 3. Investor Base, 2012

(Percent of total general government debt)
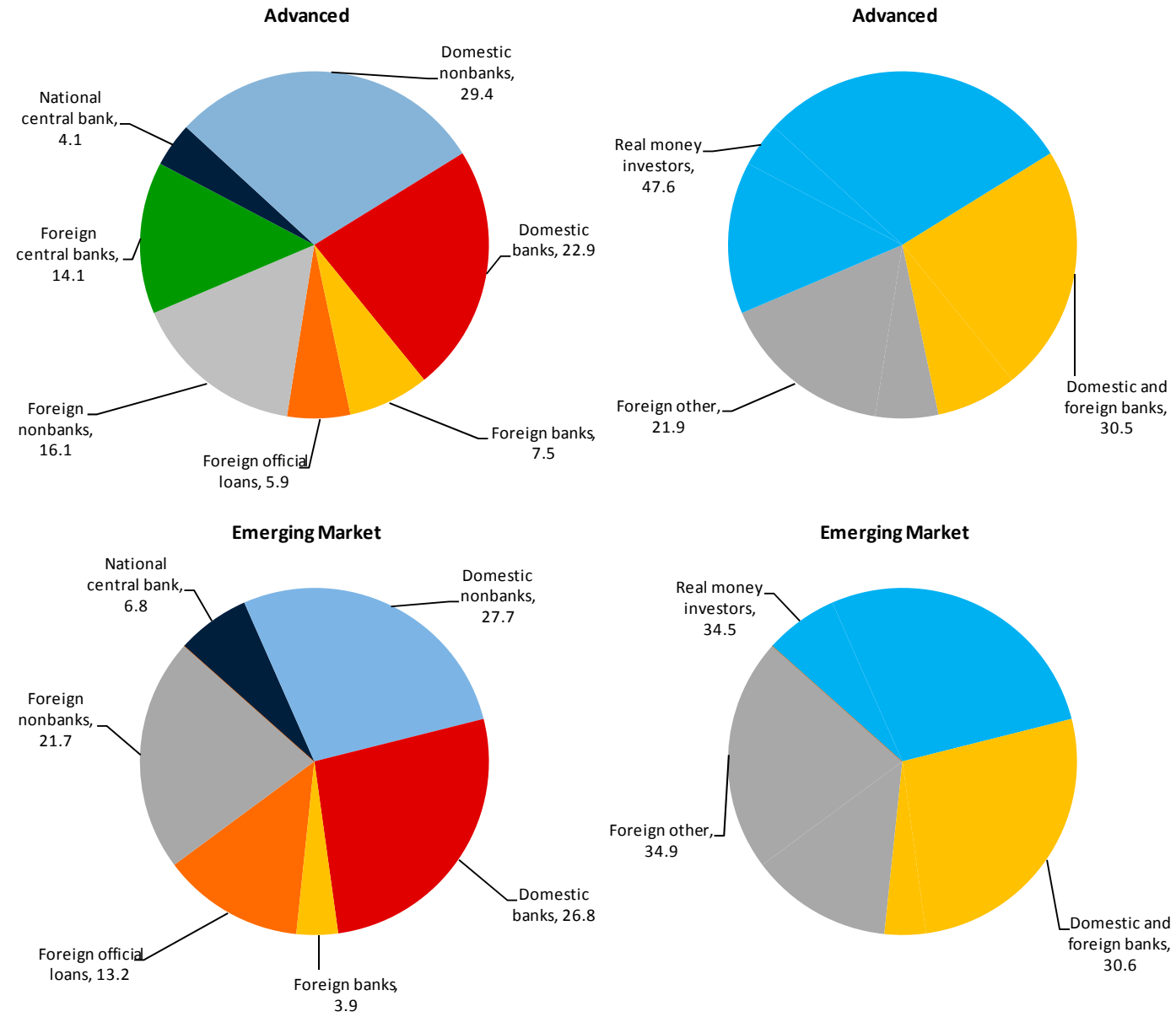

Sources: Arsanalp and Tsuda $(2012,2013)$ and authors' calculations.

Note: Unweighted averages. Real money investors include domestic nonbanks, and national and foreign central banks; foreign other includes foreign nonbanks and foreign official loans.

\footnotetext{
${ }^{6}$ For more detailed discussion of recent changes in the investor base, see Andritzky (2012) and Arsanalp and Tsuda $(2012,2013)$.
} 
Looking at trends by region, Figure 4 shows the evolution of the investor base between 2004 and 2012. The region with the highest share of real money investor holdings of public debt is in North America, where it has remained close to 70 percent, with a growing importance of foreign central banks in more recent years. In advanced Asia and Pacific countries, as well as in emerging Latin American and Asian countries, real money investors hold more than 40 percent of government debt, with a significant share held by domestic nonbanks. In European countries, both euro area and emerging market economies, the share of real money investors has been relatively lower. In euro area countries, real money investors hold about one third of total debt, while in emerging Europe this is less than 17 percent of total debt.

Figure 4. Investor Base by Region, 2004-2012

(Percent of total general government debt)
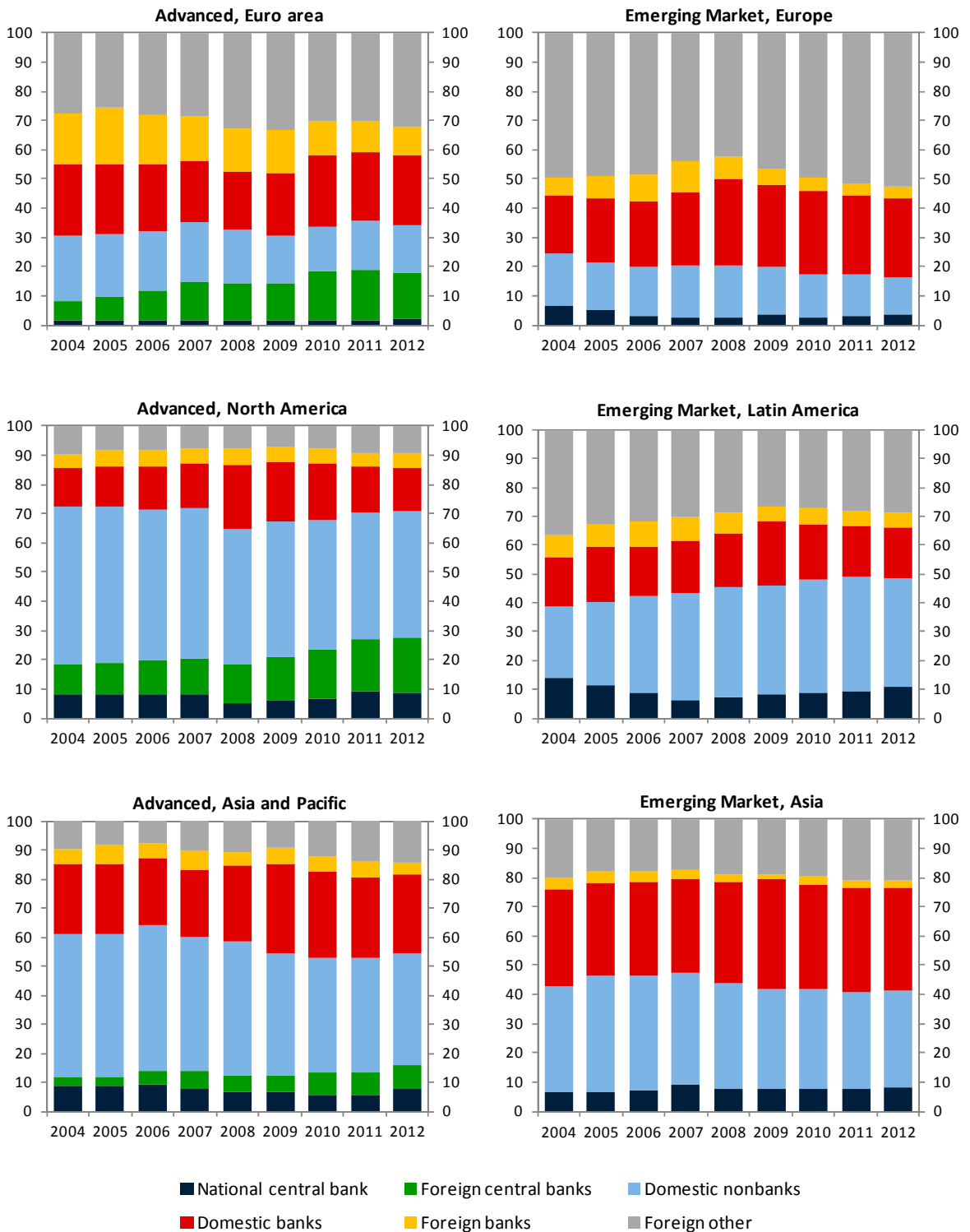

Sources: Arsanalp and Tsuda $(2012,2013)$ and authors' calculations.

Note: Unweighted averages. Real money investors include domestic nonbanks, and national and foreign central banks; foreign other includes foreign nonbanks and foreign official loans. 
The breakdown by country provides further insights into the effect on the investor base for market developments. Figure 5 depicts the real money investor holdings at end-2007, before the Lehman collapse. It is notable that countries that faced greater market pressures when the crisis unfolded (Greece, Belgium, Spain, Portugal, Italy and Ireland) were also those with the lowest share of real money investors at the outset of the crisis. In contrast, countries like the United Kingdom, the United States, and Japan, which have not been subject to market pressures despite large increases in debt-to-GDP ratios, were also those with the largest shares of debt held by real money investors. In the case of emerging economies, Bulgaria, Lithuania, Romania and Latvia, which also saw their borrowing costs rise in the context of the crisis, were the ones with lower shares of debt held by real money investors. In contrast, emerging market countries in Asia and Latin America that did not see much movement in their bond yields with the crisis, despite relatively high debt (India and Brazil), showed the largest share of real money investors. $^{7}$

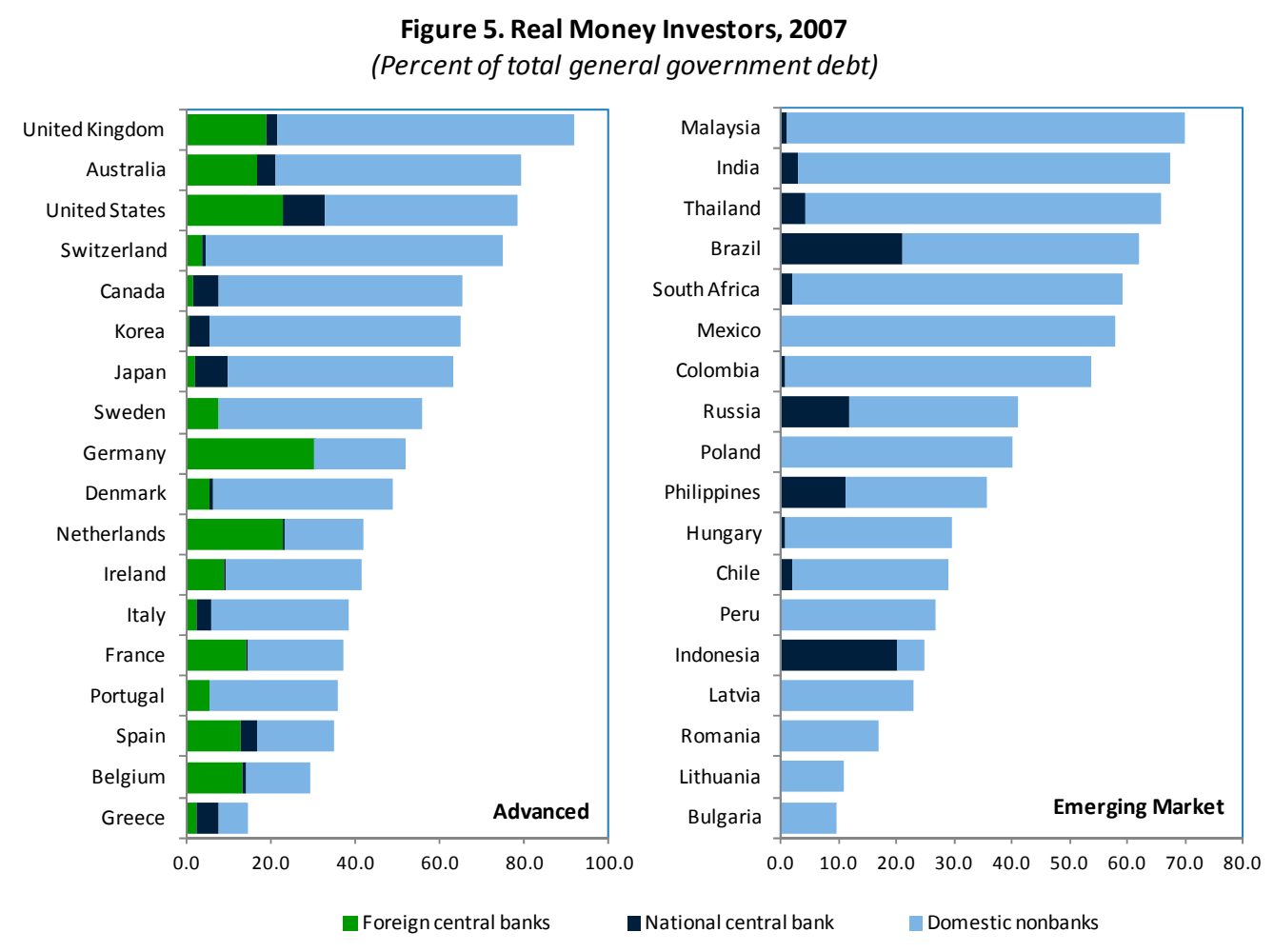

Sources: Arsanalp and Tsuda $(2012,2013)$, World Economic Outlook and authors' calculations.

\footnotetext{
${ }^{7}$ For some countries, general government debt is not made up exclusively of securitized debt. Nonetheless, government bond yields capture credit risk, which is affected by total government liabilities not only securities.
} 


\section{EMPIRICAL MODEL SPECIFICATION}

Many studies rely on fixed effects estimators to explore the determinants of sovereign bond yields (for example, Reinhart and Sack, 2000; and Baldacci and Kumar, 2010). When analyzing the impact of the investor base on sovereign bond yields, a relevant question is whether regional factors contributed to the behavior of bond yields. However, a fixed effects estimator wipes out the effects of time-invariant variables. To be able to capture the estimates of these timeinvariant variables, a Hausman and Taylor (1981) model is preferred, which allows some of the explanatory variables to be related to unobserved individual effects. In particular, we consider the following model:

$$
y_{i t}=X_{i t} \beta+Z_{i} \gamma+\mu_{i}+v_{i t}, \quad i=1, \ldots, N ; t=1, \ldots, T
$$

Where $y_{i t}$ is the dependent variable for country $i$ over period $t ; \alpha$ is a constant; $X_{i t}$ is a vector of time-varying explanatory variables; $Z_{i}$ is a vector of time-invariant explanatory variables; $\mu_{i}$ are unobserved individual effects; and $v_{i t}$ represents disturbances that are independent across countries and time. $X$ and $Z$ are split into two sets of variables: $X=\left[X_{1} ; X_{2}\right]$ and $Z=\left[Z_{1} ; Z_{2}\right]$ where $X_{1}$ and $Z_{1}$ are assumed exogenous in that they are not correlated with $\mu_{i}$ or $v_{i t}$, while $X_{2}$ and $Z_{2}$ are endogenous because they are correlated with $\mu_{i}$ but not $v_{i t}$. The Hausman Taylor estimator then uses the individual means of the strictly exogenous regressors $\left(X_{1} ; Z_{1}\right)$ as instruments for the time invariant regressors that are correlated with the individual effects (see Baltagi 2008).

Equation (1) is estimated using as the dependent variable nominal yields on the benchmark long-term government bonds between 2004H1 and 2012 H2. The determinants of government bond yields identified in the literature (Reinhart and Sack, 2000; Baldacci and Kumar, 2010; Afonso and Rault, 2010) are used as control variables to estimate the marginal impact of participation of real money investors. Explanatory variables include one-year ahead expectations of real GDP growth, inflation, public debt to GDP, the primary balance to GDP, and the external current account balance to GDP. ${ }^{8}$ Using expectations of fiscal variables helps disentangling the effect of fiscal policy from other factors influenced by the business cycle (Laubach, 2009). Moreover, it also takes into account the forward looking behavior of financial markets. The explanatory variables related to the investor base in the regression analysis include holdings of general government debt by domestic nonbanks, national and foreign central banks, domestic banks and foreign banks. ${ }^{9}$ The holdings by the ECB of government debt in the context of the Securities Market Programme (SMP) are included as an additional regressor, as these purchases did not follow the traditional investment practices of central banks and were

\footnotetext{
${ }^{8}$ In addition, all variables are also lagged by one six-month period to control for endogeneity.

${ }^{9}$ Foreign nonbanks are kept as the control group because in the Arslanalp and Tsuda (2012, 2013) dataset this is the residual category, and therefore it may be affected by the possible measurement errors of all the other categories of nonresident holders.
} 
motivated specifically to reduce market pressures in a particular set of countries. ${ }^{10} \mathrm{We}$ also include a measure of the short-term nominal interest rate (to control for the effects of monetary policy on the term structure) and a measure of global risk aversion proxied by the VIX (to control for external developments). ${ }^{11}$ Regional dummies are included for the euro area, advanced Asia and Pacific countries, advanced North American countries, emerging Asia, emerging Latin America, and emerging Europe. Dummies were also included for countries with reserve currencies outside the euro (United States, United Kingdom, and Japan) and for countries with IMF programs. Time dummies were also included. We classified the VIX, inflation and the external current account balances as exogenous time varying variables $\left(X_{1}\right)$ and the regional dummies as the exogenous time invariant variables $\left(X_{2}\right)$. All the other variables were assumed to be endogenous variables $\left(Z_{1} ; Z_{2}\right)$.

Several approaches are used to address possible endogeneity issues. Possible omitted variable bias is addressed through the Hausman Taylor model, which allows for some of the explanatory variables to be related to unobserved individual effects. Time dummies are also included to control for unidentified global factors. To address the issue of direction of causality, all variables are lagged by one six-month period. In addition, Wald statistics find that the regressors are jointly significant, suggesting that the direction of causality runs from the investor base to bond yields. More broadly, the underlying hypothesis of the empirical exercise is anchored in the theoretical models of preferred-habitat investors, which identify causality from the investor base to yields.

\section{DAta ANd Methodology}

\section{A. Data Sources}

The regression analysis is based on a panel dataset of 45 countries, 24 advanced and 21 emerging market economies with semi-annual observations from 2004 to 2012. The paper uses benchmark long-term government bond yields (typically 10-year) and short-term interest rates (3-month Treasury bill rate) from the IMF's International Financial Statistics, Bloomberg L.P., and Haver Analytics. These are averaged over the corresponding six-month period. The one-year ahead expectations for macroeconomic variables (real GDP growth, 12-month inflation, general government gross public debt to GDP, general government primary balance to GDP, and external current account deficit to GDP) are drawn on a semi-annual basis from the

\footnotetext{
${ }^{10}$ The measure of central bank holdings of general government debt already includes ECB holdings related to SMP purchases. Excluding the SMP purchases from the central bank holdings measure does not alter the regression results.

${ }^{11}$ This Chicago Board Options Exchange Volatility Index (VIX) is a measure of the market's expectation of stockmarket volatility over the next 30-day period and is a weighted blend of prices for a range of options on the S\&P 500 index.
} 
Spring and Fall editions of the World Economic Outlook (WEO). The VIX and VSTOXX is obtained from Bloomberg, L.P. ${ }^{12}$

Data on the sovereign investor base is from Arslanalp and Tsuda (2012) for advanced economies and Arslanalp and Tsuda (2013) for emerging economies. This comprehensive dataset for 24 advanced and 24 emerging market economies between 2004 and 2012 has several advantages. It ensures a common definition of sovereign debt: general government gross debt on a consolidated basis. It provides a common estimation methodology to ensure cross-country comparability based on harmonized international data sources, such as the Bank for International Settlements, IMF, and World Bank. Also, all data are compiled either in face value or adjusted for valuation changes, where appropriate. From this database, we draw five investor classes to be included in the regression analysis: foreign central banks, domestic central bank, domestic nonbanks, domestic banks, and foreign banks. Banks comprise depository corporations other than central banks, based on the definition used in the IMF's International Financial Statistics. Domestic nonbanks include institutional investors other than banks (insurance companies, pension funds, and investment funds), as well as retail investors (households and non-financial corporations). ${ }^{13}$ Foreign central bank holdings comprise government securities held by foreign central banks as foreign exchange reserves and include those held within the Eurosystem as part of the SMP. For the regression analysis, investor base data is transformed into a percentage of GDP. Percent of GDP is used instead of the percent of total general government debt because this makes the size of the market intervention comparable across countries. As the regression already controls for the debt to GDP ratio, one could not expect the impact of domestic nonbanks in Japan and Denmark for example-which hold about 45 percent of total general government debt in both cases - to be the same if this corresponds to 105 percent of GDP in the former and 22 percent of GDP in the latter.

\section{B. Results and Policy Implications}

Table 1 shows the results of the empirical analysis based on a fixed effects model for the full sample of countries (column 1), and also dividing the sample into advanced economies (column 2) and emerging market economies (column 3). Table 2 shows the results based on the Hausman-Taylor model, also dividing the sample into advanced and emerging market economies. While the results are comparable across the fixed effects and Hausman-Taylor models, the latter is preferred because it addresses endogeneity issues and it allows the inclusion of time invariant explanatory variables which are important for the question at hand. A Hausman (1978) test comparing the two models finds that the difference in coefficients is not systematic and therefore the use of the Hausman-Taylor model is valid. ${ }^{14}$ Table 3 shows the

\footnotetext{
12 The VStoxx is a measure of volatility in the euro zone, based on the EURO STOXX 50 options prices. The index covers Austria, Belgium, Finland, France, Germany, Greece, Ireland, Italy, Luxembourg, the Netherlands, Portugal and Spain.

${ }^{13}$ While household or non-financial corporate holdings of government debt account for a sizable portion of nonbanks in some countries (Italy and U.K.), institutional investors usually make up the bulk of nonbank holdings.

14 Though Pesaran's ADF test for panel data finds some variables to be I(1), the Kao residual cointegration test based on Schwarz lag length selection confirms panel cointegration.
} 
results of the Hausman Taylor model for advanced economies, having national and foreign central bank holdings as separate variables (as shown earlier, foreign central bank holdings are not relevant for emerging market economies). The variables are both found to be statistically significant determinants of bond yields, but the coefficients are not found to be statistically different from each other, therefore the discussion will focus on the coefficient on national and foreign central banks combined.

The results in Table 2 confirm the relationship between real money investor holdings of government debt and sovereign bond yields: while bond yields rise with the debt ratio, they fall with the share of the debt that is in the hands of real-money investors. An increase in the oneyear-ahead expected gross public debt-to-GDP ratio of 1 percentage point increases nominal yields by 2 basis points for the full sample, ranging from 1 basis point in the case of advanced economies to 3 basis points in the case of emerging market economies. This is in the lower range of estimates found in previous studies for advanced economies - where the estimated impact of a change of one percent of GDP in the debt ratio on interest rates ranges from 1 to 8 basis points (Haugh and others, 2009) - and somewhat below previous findings for emerging market economies - where Baldacci and Kumar (2010) and Jaramillo and Weber (2012) find an effect of 4-6 basis points for every 1 percentage point change in debt to GDP. The coefficient on the fiscal deficit was not found to be significant in any of the specifications, as the fiscal position captured by the debt variable. ${ }^{15}$

In the full sample, the coefficients on real money investors are negative and significant, and larger than the coefficient on debt. This implies that the impact on bond yields from higher debt can be mitigated if it falls in the hands of real money investors. In advanced economies, for every 1 percent of GDP in government debt held by domestic nonbanks and central banks, bond yields are expected to be lower by 3 basis points and 4 basis points, respectively.

- The impact of foreign central bank holdings on bond yields is on the higher end of the findings in other studies. Warnock and Warnock (2009) estimate the impact of foreign inflows on U.S. long-term interest rates to be 89 basis points, while Krishnamurthy and Vissing (2010) find that the impact would be 59 basis points relative to the corporate bond yield. The literature survey provided by ECB (2006) on the impact of total foreign central bank holdings of government debt in the U.S. show a range of 30-200 basis points. Our results, on a comparable basis and keeping all else equal, come in the uppermiddle part of this range at 118 basis points.

- $\quad$ The impact of domestic central bank holdings is close to that found in other studies. D'Amico and King (2010) find that the 2009 LSAP by the U.S. Federal Reserve had a persistent downward shift in the yield curve of 50 basis points, while we find an impact of 40 basis points on a comparable basis. Joyce and others (2011) find that asset purchases by the Bank of England depressed medium-term yields by 100 basis points, while we find 96 basis when put on a comparable basis.

\footnotetext{
${ }^{15}$ We explored nonlinearities by adding the a squared term of the debt-to-GDP ratio, as in Baldacci and Kumar (2010), but did not find it to be significant.
} 
- $\quad$ On the domestic nonbank holdings, the coefficient appears to be somewhat lower than other studies. Andritzky (2012) finds a coefficient of 2.6 basis points for every percentage point increase in domestic nonbank holdings as a percent of debt. To use the same metric (percent of total debt as opposed to percent of GDP), we find that one percentage point increase in domestic nonbank holdings as a percent of total debt would reduce bond yields by 2.6 basis points only for countries with debt to GDP beyond 87 percent of GDP, which is at the $90^{\text {th }}$ percentile of our sample distribution.

Interestingly, for emerging market economies, the coefficients on domestic nonbanks and central bank holdings are higher than for advanced economies. For every percentage point of GDP increase in debt held by domestic banks, yields fall by 7 basis points. For every percentage point of GDP increase in debt held by central banks, yields fall by 18 basis points. Note that the coefficient on inflation is also significant and higher than the one on central bank holdings, which may reflect concerns that central bank holdings of government debt in emerging market economies could be the result of inflationary budget financing. Furthermore, the coefficient on foreign banks becomes highly significant, with every percentage point of GDP increase in foreign bank holdings contributing to 25 basis points higher bond yields. This result is consistent with findings about the vulnerability of emerging market economies the greater their exposure to nonresident holdings (Ferrucci, 2003; Bellas and others, 2010; and Dell'Erba and others, 2013), though not with the findings of Peiris (2010).

The impact of other significant explanatory variables is as expected and in line with the previous literature (Reinhart and Sack, 2000; Afonso and Rault, 2010; Baldacci and Kumar, 2010; Jaramillo and Weber, 2012). Higher expected growth leads to a compression in yields in the case of emerging market economies, though not for advanced economies. This suggests that in the case of emerging economies, higher real GDP growth reduces credit risk as it makes the country's debt burden easier to service. Furthermore, the reduction in bond yields from higher growth in emerging economies would be partly offset if this is met with a surge in inflation. The external current account balance is found to be significant and negative only for advanced economies, suggesting that a wider current account deficit is linked to expectations of future exchange rate depreciation that pushes bond yields up. Global risk aversion is found only to be significant in the case of emerging economies, contributing to higher yields. The short-term interest rate is significant and positive in all cases. Though the regional dummies are significant in the full sample (for reserve currency countries, the euro area, emerging Asia and emerging Latin America), only the dummies for advanced Asia and Pacific and emerging Europe are significant when the sample is split. While advanced Asia and Pacific countries tend to have higher bond yields than their advanced economy peers, emerging European countries are found to have lower bond yields than the other emerging market regions.

The results were robust to alternative specifications. The size, sign, and significance of the coefficients on the investor base variables remain broadly the same when using 5-year ahead expectations of the growth, inflation, general government debt, general government primary balance, and external current account balance. The results also remain broadly unchanged if the Vstoxx is used instead of the VIX. Additional variables were introduced, but proved to be insignificant, namely the one-year ahead expected exchange rate depreciation and the volatility of bank returns. The results are also robust if the three euro area program countries are excluded 
from the sample. Similar results are also obtained when using an alternative dataset of annual observations from 2000 to 2012 for 30 advanced and 13 emerging market economies, drawing on national sources for the composition of the investor base instead of Arslanalp and Tsuda (2012, 2013). Though this annual dataset provides a longer time span, data from Arslanalp and Tsuda $(2012,2013)$ is preferred in the main results because it provides the consistency in coverage and definitions of the investor base. ${ }^{16}$

These findings suggest that some countries with high debt to GDP ratios may be able to borrow further without impacting bond yields if real money investors hold on to a considerable part of their debt. However, there is the risk that capacity for such investors to absorb public debt could diminish over the long term for some of these countries. For example, Tokuoka (2010) underscores the risk that in Japan population ageing will reduce savings inflows, which would curb growth of domestic nonbanks. In the case of the United States, Chinese central bank demand for U.S. Treasuries could decline if it decides to diversify away from these securities or as it implements policies to slow the accumulation of foreign exchange reserves (Morrison and Labonte, 2013). Also, quantitative easing strategies by national central banks in the U.K. and the U.S. are also expected to eventually unwind. In India, proposals for financial sector reform have included to steadily expand the range of assets in which pension funds and insurance companies can invest (Rajan, 2008; Herd and others, 2011), which would reduce the extent to which the government can rely on domestic nonbanks for financing. It is therefore essential that countries with high debt to GDP ratios reduce the risk of higher financing costs by moving steadily ahead with medium-term fiscal consolidation.

\section{SUMmary AND CONCluSions}

The empirical evidence confirms the relationship between real money investor holdings of government debt and sovereign bond yields. Using a panel dataset for 45 advanced and emerging market economies at semi-annual frequency during the period 2004-2012, econometric results indicate that while bond yields rise with the debt to GDP ratio, the increase is partly offset if this debt falls in the hands of domestic nonbanks or national and foreign central banks. Though the negative coefficient on central bank holdings in emerging market economies is considerably larger than for advanced economies, this is counterbalanced if central bank intervention results in inflationary financing.

These findings suggest that in the near term, real money investors help to lower bond yields, but they also underscore the importance of debt reduction efforts by countries with high debt-toGDP ratios over the medium-term. There is the risk that capacity for such investors to absorb public debt could to diminish over the long term for some countries, as the size of these investors stalls or as they diversify away from government securities. Countries with high debt to GDP ratios are especially vulnerable. Therefore, these countries should seek to reduce risk by implementing steady fiscal consolidation to bring debt-to-GDP ratios to more adequate levels.

\footnotetext{
${ }^{16}$ Results of robustness checks are available from the authors upon request.
} 
There are several directions for further research. In particular, it would be interesting to analyze whether there are any diminishing effects of real money investor holdings of government debt on bond yields. It would also be worth exploring the possible effects of the new international regulatory framework for banks and the shadow banking system on the holdings of sovereign bonds across investor classes. Another interesting question would be whether real money investors reduce the volatility of bond yields. These topics, which go beyond the scope of this paper, are left for future analysis. 
Table 1. Determinants of Sovereign Bond Yields, Fixed Effects Model

\begin{tabular}{|c|c|c|c|}
\hline & $\begin{array}{c}(1) \\
\text { All countries } \\
\end{array}$ & $\begin{array}{c}(2) \\
\text { Advanced } \\
\end{array}$ & $\begin{array}{c}(3) \\
\text { Emerging market }\end{array}$ \\
\hline Short-term interest rate, percent, lagged & $\begin{array}{c}0.163^{* * *} \\
(3.087)\end{array}$ & $\begin{array}{c}0.376^{* * *} \\
(4.966)\end{array}$ & $\begin{array}{r}0.077 \\
(1.427)\end{array}$ \\
\hline Public debt expectations $t+1$, percent of GDP, lagged & $\begin{array}{r}0.017 \\
(1.284)\end{array}$ & $\begin{array}{r}0.012 \\
(0.928)\end{array}$ & $\begin{array}{r}0.030 \\
(0.987)\end{array}$ \\
\hline Primary balance expectations $t+1$, percent of GDP, lagged & $\begin{array}{l}-0.013 \\
(-0.386)\end{array}$ & $\begin{array}{l}-0.063 \\
(-1.485)\end{array}$ & $\begin{array}{l}-0.041 \\
(-0.759)\end{array}$ \\
\hline Real GDP growth expectations $t+1$, percent, lagged & $\begin{array}{c}-0.434^{\star \star *} \\
(-4.248)\end{array}$ & $\begin{array}{l}0.027 \\
(0.163)\end{array}$ & $\begin{array}{c}-0.389^{\star * *} \\
(-3.464)\end{array}$ \\
\hline Inflation expectations $t+1$, percent, lagged & $\begin{array}{l}0.157 \\
(0.987)\end{array}$ & $\begin{array}{l}-0.246 \\
(-1.149)\end{array}$ & $\begin{array}{r}0.155 \\
(1.036)\end{array}$ \\
\hline $\begin{array}{l}\text { External current account balance expectations } t+1 \text {, percent of GDP, } \\
\text { lagged }\end{array}$ & $\begin{array}{l}-0.026 \\
(-0.949)\end{array}$ & $\begin{array}{l}-0.051 \\
(-0.867)\end{array}$ & $\begin{array}{l}-0.030 \\
(-1.490)\end{array}$ \\
\hline $\begin{array}{l}\text { Domestic nonbank holdings of government debt, percent of GDP, } \\
\text { lagged }\end{array}$ & $\begin{array}{l}-0.028^{*} \\
(-1.835)\end{array}$ & $\begin{array}{l}-0.009 \\
(-0.387)\end{array}$ & $\begin{array}{l}-0.087^{*} \\
(-1.966)\end{array}$ \\
\hline $\begin{array}{l}\text { National and foreign central bank holdings of government debt, } \\
\text { percent of GDP, lagged }\end{array}$ & $\begin{array}{r}-0.045^{\star} \\
(-1.902)\end{array}$ & $\begin{array}{l}-0.044^{*} \\
(-1.906)\end{array}$ & $\begin{array}{l}-0.231^{*} \\
(-1.828)\end{array}$ \\
\hline Domestic bank holdings of government debt, percent of GDP, lagged & $\begin{array}{r}0.005 \\
(0.338)\end{array}$ & $\begin{array}{l}-0.012 \\
(-0.555)\end{array}$ & $\begin{array}{l}-0.082 \\
(-1.612)\end{array}$ \\
\hline Foreign bank holdings of government debt, percent of GDP, lagged & $\begin{array}{l}-0.011 \\
(-0.323)\end{array}$ & $\begin{array}{r}0.002 \\
(0.063)\end{array}$ & $\begin{array}{c}0.298^{* *} \\
(2.400)\end{array}$ \\
\hline $\begin{array}{l}\text { ECB Securities Market Program holdings of government debt, } \\
\text { percent of GDP, lagged }\end{array}$ & $\begin{array}{c}0.623^{* * *} \\
(10.910)\end{array}$ & $\begin{array}{c}0.516^{\star * *} \\
(7.996)\end{array}$ & \\
\hline Dummy for IMF program countries & $\begin{array}{r}0.603 \\
(1.683)\end{array}$ & $\begin{array}{c}3.833^{* * *} \\
(5.256)\end{array}$ & $\begin{array}{r}0.215 \\
(0.661)\end{array}$ \\
\hline VIX index & $\begin{array}{r}0.004 \\
(0.845)\end{array}$ & $\begin{array}{r}0.007 \\
(1.253)\end{array}$ & $\begin{array}{c}0.016^{* \star *} \\
(3.264)\end{array}$ \\
\hline Constant & $\begin{array}{c}5.313^{* * *} \\
(6.636)\end{array}$ & $\begin{array}{l}2.979^{* *} \\
(2.135)\end{array}$ & $\begin{array}{c}7.606^{* * *} \\
(5.495)\end{array}$ \\
\hline $\begin{array}{l}\text { Observations } \\
\text { Number of countries }\end{array}$ & $\begin{array}{c}641 \\
40\end{array}$ & $\begin{array}{c}385 \\
23\end{array}$ & $\begin{array}{c}256 \\
17\end{array}$ \\
\hline R-squared & 0.615 & 0.728 & 0.526 \\
\hline
\end{tabular}


Table 2. Determinants of Sovereign Bond Yields, Hausman-Taylor Model

\begin{tabular}{|c|c|c|c|}
\hline & $\begin{array}{l}1) \\
\text { All countries }\end{array}$ & $\begin{array}{l}(2) \\
\text { Advanced }\end{array}$ & $\begin{array}{l}(3) \\
\text { Emerging market }\end{array}$ \\
\hline \multicolumn{4}{|l|}{ Endogenous variables } \\
\hline Short-term interest rate, percent, lagged & $\begin{array}{l}0.188^{\star \star *} \\
(6.211)\end{array}$ & $\begin{array}{l}0.366^{\star \star *} \\
(6.475)\end{array}$ & $\begin{array}{l}0.096^{* *} \\
(2.445)\end{array}$ \\
\hline Public debt expectations $t+1$, percent of GDP, lagged & $\begin{array}{l}0.020^{\star \star \star} \\
(3.066)\end{array}$ & $\begin{array}{l}0.013^{\star \star} \\
(2.154)\end{array}$ & $\begin{array}{l}0.033^{\star *} \\
(2.275)\end{array}$ \\
\hline Primary balance expectations $t+1$, percent of GDP, lagged & $\begin{array}{l}-0.020 \\
(-0.761)\end{array}$ & $\begin{array}{l}-0.006 \\
(-0.229)\end{array}$ & $\begin{array}{l}-0.052 \\
(-1.059)\end{array}$ \\
\hline Real GDP growth expectations $t+1$, percent, lagged & $\begin{array}{l}-0.427^{* * *} \\
(-9.289)\end{array}$ & $\begin{array}{l}-0.087 \\
(-1.203)\end{array}$ & $\begin{array}{l}-0.421^{* \star *} \\
(-7.919)\end{array}$ \\
\hline Domestic nonbank holdings of government debt, percent of GDP, lagged & $\begin{array}{l}-0.033^{\star *} \\
(-2.025)\end{array}$ & $\begin{array}{l}-0.030^{* *} \\
(-2.039)\end{array}$ & $\begin{array}{l}-0.073^{\star *} \\
(-1.962)\end{array}$ \\
\hline $\begin{array}{l}\text { National and foreign central bank holdings of government debt, percent of } \\
\text { GDP, lagged }\end{array}$ & $\begin{array}{l}-0.042^{* *} \\
(-2.435)\end{array}$ & $\begin{array}{l}-0.042^{* * *} \\
(-2.676)\end{array}$ & $\begin{array}{l}-0.175^{\star *} \\
(-2.474)\end{array}$ \\
\hline Domestic bank holdings of government debt, percent of GDP, lagged & $\begin{array}{l}0.008 \\
(0.517)\end{array}$ & $\begin{array}{l}-0.007 \\
(-0.496)\end{array}$ & $\begin{array}{l}-0.063 \\
(-1.287)\end{array}$ \\
\hline Foreign bank holdings of government debt, percent of GDP, lagged & $\begin{array}{l}-0.028 \\
(-0.984)\end{array}$ & $\begin{array}{l}-0.002 \\
(-0.099)\end{array}$ & $\begin{array}{l}0.246^{\star *} \\
(2.218)\end{array}$ \\
\hline $\begin{array}{l}\text { ECB Securities Market Program holdings of government debt, percent of } \\
\text { GDP, lagged }\end{array}$ & $\begin{array}{l}0.600^{* * *} \\
(12.950)\end{array}$ & $\begin{array}{l}0.510^{\star * *} \\
(11.250)\end{array}$ & \\
\hline Dummy for IMF program countries & $\begin{array}{l}0.609^{\star * *} \\
(3.088)\end{array}$ & $\begin{array}{l}3.326^{\star * *} \\
(6.448)\end{array}$ & $\begin{array}{l}0.227 \\
(0.924)\end{array}$ \\
\hline \multicolumn{4}{|l|}{ Exogenous, time invariant variables } \\
\hline Dummy for reserve currency countries & $\begin{array}{l}-3.447^{*} \\
(-1.694)\end{array}$ & $\begin{array}{l}-1.089 \\
(-0.710)\end{array}$ & \\
\hline Dummy for Euro area countries & $\begin{array}{l}-1.105^{*} \\
(-1.722)\end{array}$ & $\begin{array}{l}-0.127 \\
(-0.381)\end{array}$ & \\
\hline Dummy for North American advanced economies & $\begin{array}{l}-0.319 \\
(-0.331)\end{array}$ & $\begin{array}{l}0.614 \\
(1.391)\end{array}$ & \\
\hline Dummy for Asian advanced economies & $\begin{array}{l}0.441 \\
(0.551)\end{array}$ & $\begin{array}{l}0.588 \\
(1.584)\end{array}$ & \\
\hline Dummy for Asian emerging markets & $\begin{array}{l}1.582^{*} \\
(1.908)\end{array}$ & & $\begin{array}{l}-0.238 \\
(-0.099)\end{array}$ \\
\hline Dummy for European emerging markets & $\begin{array}{l}1.090^{*} \\
(1.652)\end{array}$ & & $\begin{array}{l}-2.207 \\
(-1.101)\end{array}$ \\
\hline Dummy for Latin American emerging markets & $\begin{array}{l}3.097^{* \star *} \\
(4.538)\end{array}$ & & $\begin{array}{l}0.634 \\
(0.307)\end{array}$ \\
\hline \multicolumn{4}{|l|}{ Exogenous, time variant variables } \\
\hline VIX index & $\begin{array}{l}-0.000 \\
(-0.044)\end{array}$ & $\begin{array}{l}-0.003 \\
(-0.463)\end{array}$ & $\begin{array}{l}0.016^{\star *} \\
(2.211)\end{array}$ \\
\hline Inflation expectations $t+1$, percent, lagged & $\begin{array}{l}0.223^{\star \star *} \\
(5.067)\end{array}$ & $\begin{array}{l}-0.207 \\
(-1.269)\end{array}$ & $\begin{array}{l}0.199^{\star \star \star} \\
(3.184)\end{array}$ \\
\hline $\begin{array}{l}\text { External current account balance expectations } t+1 \text {, percent of GDP, } \\
\text { lagged }\end{array}$ & $\begin{array}{l}-0.022 \\
(-1.258)\end{array}$ & $\begin{array}{l}-0.044^{* *} \\
(-2.292)\end{array}$ & $\begin{array}{l}-0.029 \\
(-1.049)\end{array}$ \\
\hline Constant & $\begin{array}{l}4.878^{* \star *} \\
(7.818)\end{array}$ & $\begin{array}{l}3.803^{* * *} \\
(7.604)\end{array}$ & $\begin{array}{l}8.120^{\star \star *} \\
(4.176)\end{array}$ \\
\hline Observations & 641 & 385 & 256 \\
\hline Number of countries & 40 & 23 & 17 \\
\hline Wald-statistics & 1033 & 1213 & 246 \\
\hline
\end{tabular}

\section{CInternational Monetary Fund. Not for Redistribution}


Table 3. Determinants of Sovereign Bond Yields, Hausman-Taylor Model

Advanced economies

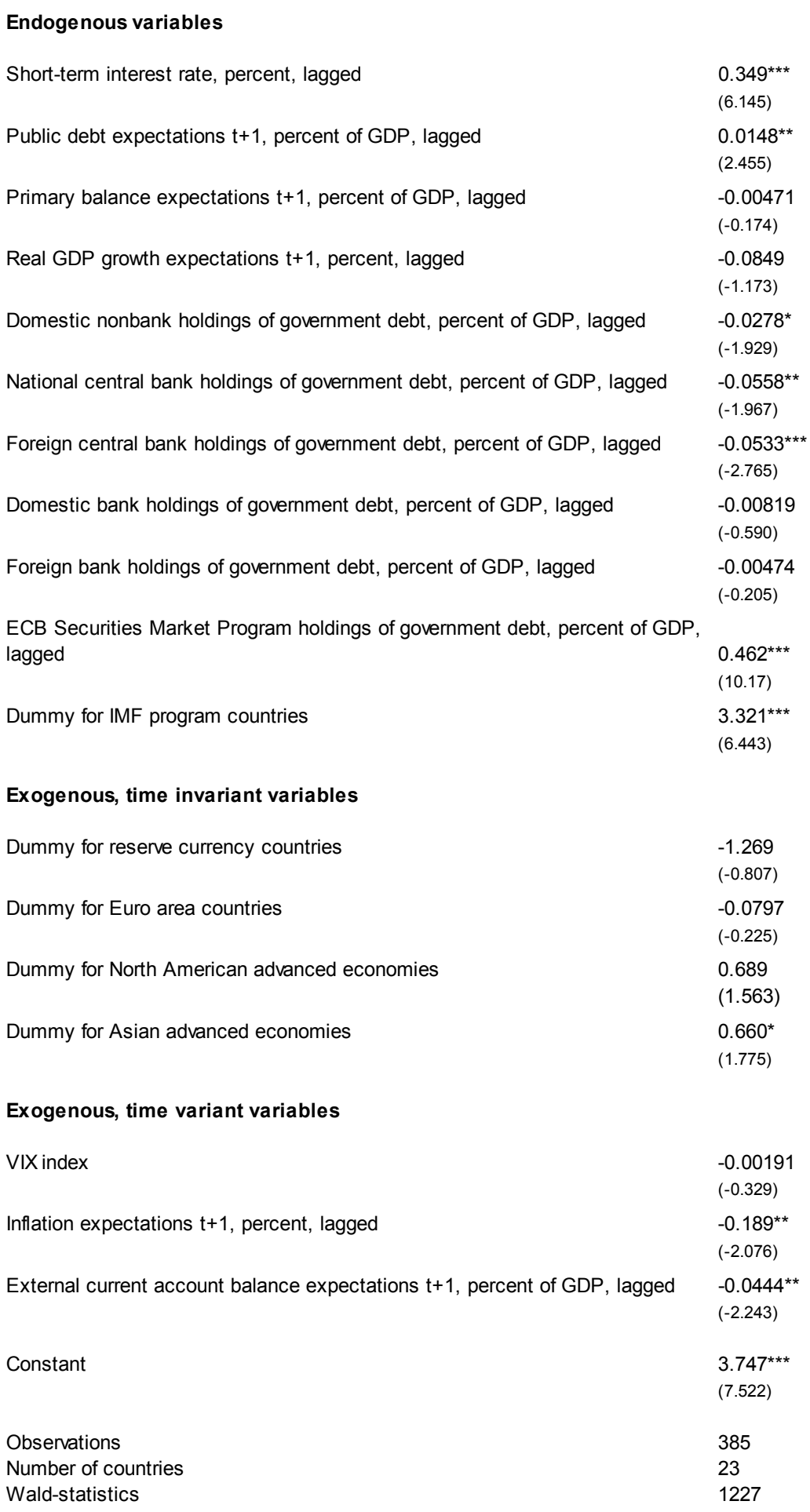

z-statistics in parentheses

${ }^{* * *} p<0.01,{ }^{* *} p<0.05,{ }^{*} p<0.1$

\section{CInternational Monetary Fund. Not for Redistribution}




\section{REFERENCES}

Afonso, A., and C. Rault, 2010, "Short and Long-run Behaviour of Long-term Sovereign Bond Yields”, CESifo Working Paper No. 3249.

Andritzky, J., 2012. "Government Bonds and Their Investors: What Are the Facts and Do They Matter?" IMF Working Paper No. 12/158.

Arslanalp, S. and W. R. Lam, 2013, “Outlook for Interest Rates and Japanese Banks' Risk Exposures under Abenomics”, IMF Working Paper No. 13/213

Arslanalp, S. and T. Poghosyan, 2013. "Foreign Investor Base and Long-term sovereign Bond Yields in Advanced Economies". IMF Working Paper (forthcoming)

Arslanalp, S. and T. Tsuda, 2012. "Tracking Global Demand for Advanced Economy Sovereign Debt”, IMF Working Paper No. 2/284, December.

Arslanalp, S. and T. Tsuda, 2013. "Tracking Global Demand for Emerging Market Sovereign Debt”, IMF Working Paper (forthcoming).

Baldacci, E., and M. Kumar, 2010, "Fiscal Deficits, Public Debt, and Sovereign Bond Yields," IMF Working Paper 10/184.

Baltagi, B. H., 2008. Econometric Analysis of Panel Data- $4^{\text {th }}$ Edition, New York: John Wiley $\&$ Sons.

Bellas, D., M. G. Papaioannou, and I. Petrova, 2010. "Determinants of Emerging Market Sovereign Bond Spreads: Fundamentals vs Financial Stress", IMF Working Paper No. 10/281.

Beltran, D., M. Kretchmer, J. Marquez, and C. Thomas, 2012, ’Foreign Holdings of U.S. Treasuries and U.S. Treasury Yields," International Finance Discussion Papers No. 1041, Federal Reserve Board, Washington D.C.

Chen, X., Z. Sun, T. Yao, and T. Yu, 2013, "In Search of Habitat”, working paper.

Cox, J., J. Ingersoll, and S. Ross, 1985, "A Theory of the Term Structure of Interest Rates", Econometrica, 53, 385-408

Culbertson, J. M. 1957. “The Term Structure of Interest Rates.” Quarterly Journal of Economics, 71(4): 485-517.

D’Amico, S., and T. King, 2010, "Flow and Stock Effects of Large-Scale Treasury Purchases," Finance and Economics Discussion Series Working Paper No. 2010-52, Federal Reserve Board, Washington, D.C. 
D’Amico, S., W. English, D. Lopez-Salido, and E. Nelson, 2012, “The Federal Reserve's Large-Scale Asset Purchase Programs: Rationale and Effects," Finance and Economics Discussion Series Working Paper No. 2012-85, Federal Reserve Board, Washington, D.C.

Dell'Erba, S., R. Hausmann, and U. Panizza, 2013, "Debt Levels, Debt Composition, and Sovereign Spreads in Emerging and Advanced Economies", CID Working Paper No. 263, August.

European Central Bank (ECB), 2006, “The Accumulation of Foreign Reserves," ECB Occasional Paper Series No. 43.

Ferrucci, G., 2003, "Empirical Determinants of Emerging Market Economies Sovereign Bond Spreads," Bank of England Working Paper No. 205

Gagnon, J., M. Raskin, J. Remache, and B. Sack, 2010, "Large-Scale Asset Purchases by the Federal Reserve: Did They Work?” FRBNY Staff Report No. 441.

Giannetti, M., and L. Laeven, 2012, “The Flight Home Effect: Evidence from the Syndicated Loan Market during Financial Crises,” Journal of Financial Economics, Vol. 104 (1).

Greenwood, R., and D. Vayanos, 2010, "Price Pressure in the Government Bond Market," American Economic Review: Papers \& Proceedings 100 (May2010): 585-590

Haugh, D., P. Ollivaud and D. Turner, 2009. What Drives Sovereign Risk Premiums? An Analysis of Recent Evidence from the Euro Area. OECD Economics Department Working Papers No. 718.

Hausman, J.A., 1978, “Specification Tests in Econometrics,” Econometrica, 46(6), pp. 125171.

Hausman, J.A. and W.E. Taylor, 1981, "Panel Data and Unobservable Individual Effects", Econometrica 49, 1377-1398.

Herd, R., V. Koen, I. Patnaik, and A. Shah, 2011, "Financial Sector Reform in India: Time for a Second Wave?", OECD Economics Department Working Papers, No. 879.

International Monetary Fund (IMF), 2011, Global Financial Stability Report: Grappling with Crisis Legacies, September 2011 (Washington, International Monetary Fund).

Jaramillo, L. and A. Weber, 2012. "Bond Yields in Emerging Economies: It Matters What State You Are In", IMF Working Paper No. 12/198.

Joyce, M., A. Lasaosa, I. Stevens, and M. Tong, 2011, "The Financial Market Impact of Quantitative Easing in the United Kingdom," International Journal of Central Banking, September, Vol. 7, No. 3. 
Kaminska, I., D. Vayanos, G. Zinna, 2011. "Preferred-Habitat Investors and the U.S. Term Structure of Real Interest Rates", Bank of England Working Paper No. 435.

Krishnamurthy, A., and A. Vissing-Jorgensen, 2010, “The Aggregate Demand for Treasury Debt," NBER Working Paper 12881, Cambridge, Mass.: National Bureau of Economic Research.

Laubach T., 2009, "New Evidence on the Interest Rate Effects of Budget Deficits and Debt," Journal of the European Economic Association, Vol. 7, No. 4, pp. 858-885

Modigliani, F., and R. Sutch. 1966. "Innovations in Interest-Rate Policy." American Economic Review, 56(1-2): 178-97.

Morrison, W. M., and M. Labonte, 2013, “China's Holdings of U.S. Securities: Implications for the U.S. Economy”, Congressional Research Service Report for Congress, August 19.

Peiris, S., 2010, "Foreign Participation in Emerging Markets' Local Currency Bond Markets," IMF Working Paper 10/88, April

Rajan, R., 2008. "Financial Sector Reforms in India and the Global Crisis", speech to the Institute for Economic Growth, Delhi, March 2008.

Reinhart, V., Sack, B., 2000. The Economic Consequences of Disappearing Government Debt. Brookings Papers on Economic Activity, Economic Studies Program, Vol. 31, pp. 163-209 (Washington: Brookings Institution).

Sierra, J., 2010, “International Capital Flows and Bond Risk Premia”, Bank of Canada Working Paper No. 2010-14

Tokuoka, K., 2010, “The Outlook for Financing Japan’s Public Debt,” IMF Working Paper $10 / 19$.

Vayanos, D., and J. L. Vila, 2009. "A Preferred-Habitat Model of the Term Structure of Interest Rates”, NBER Working Paper No. 15487, November.

Warnock, F. E., and V. Warnock, 2009. "International Capital Flows and U.S. Interest Rates,” Journal of International Money and Finance, Vol. 28, pages 903-19. 